\title{
Penerapan model pembelajaran problem based learning untuk meningkatkan keterampilan berpikir kritis dan hasil belajar siswa IPA kelas VIII D SMP Negeri 22 Malang
}

\author{
Annisa Rachma, Sunarmi*, Murni Saptasari \\ Universitas Negeri Malang, Jl. Semarang No. 5 Malang, Jawa Timur, Indonesia \\ *Penulis korespondensi, Surel:sumarmi.fmipa@um.ac.id \\ Paper received: 02-01-2021; revised: 15-01-2021; accepted: 30-01-2021
}

\begin{abstract}
The results of observations of class VIII SMP Negeri 22 Malang shows, students have low of the critical thinking skills and learning outcomes. Students tend to be passive and less critical. Effort to improve the quality of learning is by applying the Problem Based Learning (PBL). This research was conducted with the aim of improving students' critical thinking skills and student learning outcomes IPA in class VIII SMP Negeri 22 Malang through the implementation of $P B L$. This type of research is a Class Action Research (PTK) is a qualitative research. This research data in the form of critical thinking skills, student's learning, and enforceability of learning by using PBL. Collection technique that is a matter of cognitive tests, tests about critical thinking skills, field notes and documentation conducted by the observer. Based on exposure and research findings, obtained two conclusions. First, the critical thinking skills of students in the second cycle increases than I. Mean thinking skills of first cycle is 1.50 were classified as less critical with a percentage of 23 percent, while in the second cycle mean of critical thinking skills 2.36 is classified as critical percentage of 76 percent. From these data indicate that the critical thinking skills increased by 53 percent. Second, in classical mastery learning outcomes of students has increased from the first cycle to the second cycle. The results of classical learning in the first cycle of 67.6 percent, while in the second cycle by 80 percent. This shows an increase in cycle I and II of 30.3 percent.
\end{abstract}

Keywords: Problem Based Learning; Critical Thinking Skills; Learning Outcomes

\begin{abstract}
Abstrak
Hasil observasi pada siswa kelas VIII SMP Negeri 22 Malang menunjukkan, keterampilan berpikir kritis dan hasil belajar rendah. Siswa cenderung pasif dan kurang kritis. Salah satu usaha meningkatkan kualitas pembelajaran adalah dengan model pembelajaran Problem Based Learning (PBL).Tujuan penelitian ini meningkatkan keterampilan berpikir kritis siswa dan hasil belajar siswa kelas VIII SMP Negeri 22 Malang dengan model pembelajaran PBL. Jenis penelitian adalah Penelitian Tindak Kelas (PTK) merupakan penelitian deskriptif kualitatif. Data keterampilan berpikir kritis, hasil belajar siswa, dan keterlaksanaan pembelajaran dengan model pembelajaran PBL. Teknik pengumpulan yaitu soal tes kognitif, soal tes keterampilan berpikir kritis, catatan lapangan dan dokumentasi oleh observer. Berdasarkan paparan dan temuan penelitian, diperoleh dua simpulan. Pertama, keterampilan berpikir kritis siswa pada siklus II mengalami kenaikan dibanding siklus I. Rerata keterampilan berpikir siklus 1 sebesar 1,50 yang tergolong kurang kritis dengan persentase sebesar 23 persen sedangkan pada siklus II rerata keterampilan berpikir kritis siswa sebesar 2,36 yang tergolong kritis dengan persentase sebesar 76 persen. Dari data tersebut menunjukkan bahwa keterampilan berpikir kritis meningkat sebesar 53 persen. Kedua, secara klasikal ketuntasan hasil belajar siswa mengalami peningkatan dari siklus I ke siklus II. Hasil belajar klasikal pada siklus I sebesar 67,6 persen sedangkan pada siklus II sebesar 80 persen. Hal ini menunjukkan terjadi peningkatan pada siklus I dan II sebesar 30,3 persen.
\end{abstract}

Kata kunci: Model Pembelajaran Problem Based Learning; Keterampilan Berpikir Kritis; Hasil Belajar Siswa 


\section{Pendahuluan}

Pelajaran IPA terpadu terdiri dari tiga mata pelajaran pokok, yaitu Biologi, Fisika dan Kimia. Hasil observasi pada siswa kelas VIII SMP Negeri 22 Malang pada tanggal 25, 29 September dan 2 Oktober 2015 menunjukkan bahwa selama proses pembelajaran, siswa memiliki keterampilan berpikir kritis rendah terhadap IPA. Menurut (Ennis, 1996) indikator berpikir kritis dikelompokkan dalam lima besar aktivitas yaitu penjelasan sederhana, keterampilan dasar, menyimpulkan, penjelasan lanjut, dan mengatur strategi dan teknik. Rendahnya keterampilan berpikir kritis siswa terbukti dengan $75 \%$ dari jumlah total siswa yaitu 30 orang tidak mengajukan pertanyaan. Siswa yang aktif 6 siswa mampu memfokuskan pertanyaan, menganalisis pertanyaan dan bertanya, serta menjawab pertanyaan tentang suatu penjelasan atau pernyataan pada pembelajaran IPA. Diskusi kelompok tidak terjadi interasksi antar teman, tugas dikerjakan oleh 2-3 orang saja. Hal ini menunjukkan keterampilan berpikir kritis siswa kelas VIII rendah sehingga perlu di tingkatkan. Selain itu hasil observasi rekapan nilai guru kelas menunjukkan bahwa $70 \%$ siswa tidak memenuhi Kriteria Ketuntasan Minimal (KKM), yaitu 75 pada KD 3.4. Guru harus melakukan program remidi bagi siswa yang tidak tuntas belajar.

Salah satu usaha untuk meningkatkan kualitas pembelajaran adalah dengan menerapkan model pembelajaran Problem Based Learning (PBL) yaitu model pembelajaran yang memotivasi siswa untuk belajar aktif. Siswa dituntut terlibat untuk mengidentifikasi masalah, mengumpulkan dan menggunakan data untuk pemecahan masalah. Siswa dapat merumuskan masalah dari materi yang diajarkan sehingga siswa mampu menunjukkan tingkat berpikir kritisnya. Menurut Rusman (2010) tujuan model $P B L$ adalah: (a) membantu siswa mengembangkan keterampilan berpikir dan memecahkan masalah, (b) belajar berbagai peran orang dewasa melalui keterlibatan mereka dalam pengalaman nyata dan, (c) menjadi siswa yang mandiri. Hal ini sesuai dengan karakteristik model $P B L$ yaitu belajar tentang kehidupan yang lebih luas, keterampilan memaknai informasi, kolaboratif, dan belajar tim, serta keterampilan berpikir reflektif dan evaluatif.

Model pembelajaran $P B L$ akan diterapkan pada materi zat aditif, zat adiktif, dan sistem ekskresi untuk meningkatkan keterampilan berpikir kritis dan hasil belajar siswa kelas VIII SMP Negeri 22 Malang. Diharapkan siswa dapat membentuk pengetahuan atau konsep baru dari informasi yang didapatnya, sehingga keterampilan berpikir siswa terlatih.

\section{Metode}

Jenis penelitian yang digunakan adalah Penelitian Tindak Kelas (PTK). Pendekatan penelitian yang digunakan pada penelitian ini adalah penelitian deskriptif kualitatif. Setiap siklus pada penelitian ini terdiri atas 4 tahap yaitu (1) perencanaan tindakan, (2) pelaksanaan tindakan, (3) observasi, dan (4) refleksi. Guru model didampingi oleh 3 observer. Data hasil belajar kognitif siswa berupa skor jawaban soal tes kognitif siswa setiap akhir siklus. Data hasil belajar afektif dan psikomotor berupa skor dari rubrik penilaian afektif dan psikomotor. Data keterampilan berpikir kritis siswa berupa skor jawaban soal tes keterampilan berpikir kritis. Data keterlaksanaan pembelajaran yaitu skor pencapaian keterlaksanaan pembelajaran oleh guru dan siswa dengan menggunakan model pembelajaran Problem Based Learning.

\section{Hasil dan Pembahasan}

Pelaksanaan penelitian tindakan kelas sebanyak dua siklus memperoleh temuan penelitian yang terdiri dari keterlaksanaan pembelajaran, kemampuan berpikir kritis, dan hasil belajar siswa diuraikan berikut. 


\subsection{Keterlaksanaan pembelajaran}

Data peresentase keterlaksanaan pembelajaran oleh guru pada siklus I dan siklus II, diketahui terdapat peningkatan. Data perbandingan persentase keterlaksanaan pembelajaran oleh guru pada siklus I dan II dapat dilihat pada Tabel. 4.1.

Tabel 1. Ringkasan Data Keterlaksanaan Pembelajaran Oleh Guru Siklus I Dan II

\begin{tabular}{|c|c|c|}
\hline Siklus & $\begin{array}{l}\text { Selisih Persentase Keterlaksanaan } \\
(\%)\end{array}$ & Keterangan \\
\hline 1 & 9 & \multirow{2}{*}{ Meningkat } \\
\hline 2 & 100 & \\
\hline \multicolumn{3}{|c|}{$\begin{array}{l}\text { Berdasarkan Tabel. } 4.1 \text { dapat diketahui bahwa terjadi peningkatan persentase } \\
\text { aksanaan pembelajaran oleh guru. Pada siklus I persentase keterlaksanaan } \\
\text { lajaran sebesar 91\%. Hal ini disebabkan guru tidak menjelaskan langkah } \\
\text { lajaran, sedangkan pada siklus II menjadi 100\%. Hal ini menunjukkan terjadi } \\
\text { gkatan sebesar } 9 \% \text {. }\end{array}$} \\
\hline
\end{tabular}

\subsection{Keterampilan Berpikir Kritis}

Pelaksanaan tindakan pembelajaran PBL yang dilakukan pada siklus I dan siklus II, diketahui terdapat peningkatan hasil persentase keterampilan berpikir kritis siswa. Data perbandingan persentase keterampilan berpikir kritis siswa siklus I dan II dapat dilihat pada Tabel.4.2

Tabel 2. Ringkasan Data Keterampilan Berpikir Kritis Siswa Siklus I dan II

\begin{tabular}{|c|c|c|c|c|}
\hline Siklus & Rata-rata KBK klasikal & Kategori & Persentase KBK klasikal (\%) & Keterangan \\
\hline 1 & 1,50 & Kurang kritis & 23 & Meningkat \\
\hline 2 & 2,36 & Kritis & 76 & \\
\hline $\begin{array}{l}\text { siklus I } \\
\text { sebesa } \\
\text { siklus I } \\
\text { persen } \\
\text { berpiki }\end{array}$ & $\begin{array}{l}\text { erdasarkan Tabel } 4.2 \mathrm{~d} \\
\text { mengalami kenaikan } \mathrm{di} \\
1,50 \text { yang tergolong ku } \\
\text { rerata keterampilan be } \\
\text { ise sebesar } 76 \% \text {. Berd } \\
\text { kritis meningkat sebesa }\end{array}$ & $\begin{array}{l}\text { at diketahui b } \\
\text { anding siklus I } \\
\text { ng kritis deng } \\
\text { ikir kritis sisv } \\
\text { sarkan data } t \\
53 \% \text {. }\end{array}$ & $\begin{array}{l}\text { wa keterampilan berpikir kr } \\
\text { erata keterampilan berpikir } \\
\text { persentase sebesar } 23 \% \text { s } \\
\text { sebesar } 2,36 \text { yang tergolong } \\
\text { sebut menunjukkan bahwa }\end{array}$ & $\begin{array}{l}\text { S siswa pada } \\
\text { ritis siklus } 1 \\
\text { angkan pada } \\
\text { ritis dengan } \\
\text { reterampilan }\end{array}$ \\
\hline
\end{tabular}

\subsection{Hasil Belajar}

Peningkatan keterampilan berpikir kritis siswa diikuti dengan peningkatan hasil belajar siswa. Perbandingan hasil belajar siswa secara klasikal baik ranah kognitif, afektif dan psikomotor disajikan pada Tabel 4.3.

Tabel 3. Perbandingan Hasil Belajar Klasikal Siklus I Dan II

\begin{tabular}{llll}
\hline Hasil belajar siswa & HBK I (\%) & HBK II (\%) & Peningkatan (\%) \\
\hline Kognitif & 63 & 80 & 17 \\
Afektif & 70 & 80 & 10 \\
Psikomotor & 70 & 80 & 10 \\
Ketuntasan klasikal & 67,6 & 80 & 30,3 \\
\hline
\end{tabular}


Berdasarkan Tabel.4.3 diketahui bahwa hasil belajar klasikal pada siklus I sebesar $67,6 \%$ sedangkan pada siklus II sebesar $80 \%$. Hal ini menunjukkan terjadi peningkatan pada siklus I dan II sebesar 30,3\%.

\subsection{Penerapan Problem Based Learning (PBL) untuk Meningkatkan Keterampilan Berpikir Kritis}

Pelaksanaan tindakan pembelajaran $P B L$ pada siklus I dan siklus II, terdapat peningkatan hasil persentase keterampilan berpikir kritis siswa. Keterampilan berpikir kritis siswa pada siklus II mengalami kenaikan dibanding siklus I. Rerata keterampilan berpikir siklus 1 sebesar 1,50 yang tergolong kurang kritis dengan persentase sebesar 23\% sedangkan pada siklus II rerata keterampilan berpikir kritis siswa sebesar 2,36 yang tergolong kritis dengan persentase sebesar 76\%. Dari data tersebut menunjukkan bahwa keterampilan berpikir kritis meningkat sebesar 53\%.

Hasil tersebut memberikan makna bahwa model pembelajaran $P B L$ dapat meningkatkan keterampilan berpikir kritis siswa. Hasil temuan ini sesuai yang diungkapkan oleh Darmawan (2010) bahwa penerapan PBL meningkatkan kemampuan berpikir kritis siswa dengan menunjukkan perubahan dalam proses belajar. Peningkatan nilai kemampuan berpikir kritis siswa tidak terlepas dari karakteristik sintaks model $P B L$. $P B L$ merupakan model pembelajaran yang menekankan kemampuan berpikir siswa. Prinsip pelaksanaan pembelajaran dengan model $P B L$, yaitu dalam proses belajar, siswa dituntut melakukan pemecahan masalah yang dibahas dengan cara menggali informasi sebanyak-banyaknya, kemudian dianalisis dan dicari solusi. Solusi tidak harus satu jawaban, artinya siswa juga dituntut untuk belajar secara kreatif dan mandiri terutama dalam menggali dan memecahkan permasalahan. Siswa diharapkan menjadi individu yang berwawasan luas serta mampu melihat hubungan pembelajaran dengan aspek yang ada di lingkungannya sehingga siswa tidak hanya mempelajari teori namun juga melihat fakta di lingkungan. Barrows (1996) PBL merupakan model pembelajaran yang didasarkan pada prinsip bahwa masalah dapat digunakan sebagai titik awal untuk mendapatkan atau mengintegrasikan pengetahuan baru.

Mengembangkan kemampuan berpikir kritis siswa akan mengalami peningkatan seiring dengan model pembelajaran yang digunakan, oleh karena itu pembelajaran harus memberdayakan kemampuan berpikir kritis (Ibrahim dan Nur, 2000). Pembelajaran dengan model PBL melatih siswa berdiskusi, merumuskan masalah, menyusun hipotesis, melakukan investigasi, mempresentasikan hasil, dan menyimpulkan persoalan yang diberikan atau dipelajari. Aktivitas kerja dalam kelompok sebaya akan menjadi wahana bagi siswa untuk mengaktualisasikan potensi diri dalam meningkatkan kemampuan berpikir kritis siswa.

Pembelajaran dengan model $P B L$ mengajarkan siswa untuk berpikir kritis secara mandiri dalam mencari pemecahan masalah dalam dunia nyata berdasarkan masalah dalam pembelajaran. Siswa melakukan penyelidikan dan analisis terhadap masalah yang menjadi isu serta menyampaikan hasil penyelidikannya dalam bentuk karya. Aktivitas menuntut siswa membuat perencanaan, mengatur diri, dan mengevaluasi hasil pekerjaannya. Proses pembelajaran sesuai dengan pembelajaran kontruktivisme yang menekankan pengembangan kemampuan siswa dalam menemukan permasalahan dan jawaban masalah yang sedang dikaji. Guru diharapkan dapat memberikan motivasi pada siswa agar seluruh anggota kelompok bersatu padu untuk mengikuti pembelajaran dan diskusi siswa tidak menyimpang 
dari topik pembelajaran. Peran guru dalam model PBL menurut Rusman (2010) adalah menyiapkan perangkat berpikir siswa bertujuan agar siswa siap mengikuti pembelajaran dengan model $P B L$. Seperti, mengubah cara berpikirnya, menyiapkan siswa untuk pembaruan dan kesulitan, membantu siswa merasa memiliki masalah, dan mengkomunikasikan tujuan, hasil, dan harapan.

Hasil penelitian ini menunjukkan bahwa pembelajaran IPA dengan model $P B L$ dapat meningkatkan kemampuan berpikir kritis. Siswa yang menggunakan model $P B L$ memiliki kemampuan berpikir kritis lebih tinggi dibanding dengan siswa yang menggunakan model lain. Hal ini terjadi karena adanya keterkaitan antara sintaks $P B L$ kemampuan berpikir kritis. Permasalahan fenomena mampu merangsang siswa untuk mengajukan berbagai pertanyaan yang berhubungan dengan materi IPA. Model PBL membantu siswa berpikir secara mandiri, melakukan penyelidikan, menyelesaikan masalah, menganalisis, dan menyimpulkan masalah dalam kehidupan, sehingga berdampak pada kemampuan berpikir kritis.

\subsection{Penerapan Problem Based Learning (PBL) untuk Meningkatkan Hasil Belajar}

Hasil belajar siswa meliputi tiga ranah, yakni ranah kognitif, ranah afektif, dan ranah psikomotor yang dijabarkan pada pembahasan berikut.

\subsubsection{Hasil Belajar Kognitif}

Menurut Sudjana (2009) ranah kognitif berkenaan dengan hasil belajar intelektual. Hasil belajar kognitif siswa didapatkan dari hasil test siswa pada akhir siklus. Berdasarkan data yang diperoleh, hasil belajar siswa kognitif secara klasikal mengalami peningkatan dari siklus I sebesar 63\% menjadi $80 \%$ pada siklus II. Berdasarkan hasil data tersebut dapat diketahui hasil belajar kognitif siswa secara klasikal mengalami peningkatan $17 \%$. Kelas dapat mencapai ketuntasan belajar apabila mencapai $\geq 75 \%$ dari jumlah siswa. Kriteria Ketuntasan Minimal yang telah ditetapkan oleh SMP Negeri 22 Malang adalah 75.

Pada siklus I belum tercapai ketuntasan belajar kognitif yaitu sebesar 63\%. Hal ini disebabkan siswa belum terbiasa menghadapi permasalahan yang diberikan sehingga kebingungan dalam mengerjakan. Selain itu siswa yang aktif hanya 1-3 sehingga dalam diskusi kurang kerja sama. Sedangkan pada siklus II sudah mengalami peningkatan karena siswa banyak yang paham tentang materi yang diajarkan. Hal ini dibuktikan ketika guru memberikan pertanyaan yang berupa orientasi pada masalah, banyak siswa yang dapat menjawab. Pada kegiatan diskusi, hampir semua anggota kelompok mengerjakan lembar kegiatan siswa. Ketika tahapan menganalisis dan mengevaluasi proses pembelajaran banyak siswa yang sudah mampu memberikan refleksi hasil pembelajaran dengan baik, banyak juga yang sudah berpendapat dengan baik. Hal tersebut menunjukkan bahwa siswa sudah dapat memecahkan masalah dalam materi yang diajarkan sehingga hasil belajar kognitif pada siklus II meningkat dibandingkan siklus I. PBL merupakan informasi tertulis yang berupa masalah diberikan diawal kegiatan pembelajaran. Fokusnya adalah bagaimana siswa mengidentifikasi isu pembelajaran sendiri untuk memecahkan masalah. Materi dan konsep yang relevan ditemukan oleh siswa Slavin (2010).

Secara keseluruhan nilai hasil belajar kognitif siswa pada siklus I mengalami peningkatan pada siklus II. Hal tersebut sesuai pernyataan Rusman (2010) PBL merupakan 
penggunaan berbagai macam kecerdasan yang diperlukan untuk terlibat dalam dunia nyata, kemampuan untuk menghadapi segala sesuatu yang baru dan kompleksitas yang ada.

\subsection{Hasil Belajar Afektif}

Menurut Sudjana (2009) ranah afektif berkenaan dengan sikap dan nilai. Hasil belajar afektif yang dinilai pada siswa ada dua aspek yakni spiritual dan sosial. Tipe hasil belajar afektif tampak pada siswa dalam berbagai tingkah laku seperti berdoa sebelum dan sesudah melakukan sesuatu, mengucapkan rasa syukur atas karunia Tuhan, memberi salam sebelum dan sesudah menyampaikan pendapat/presentasi, mengungkapakan kekaguman secara lisan maupun tulisan terhadap tuhan saat melihat kebesaran Tuhan, mengerjakan tugas sendiri, mengumpulkan tugas tepat waktu, bertanggung jawab terhadap setiap tugas yang diberikan. Dalam penelitian ini, hasil belajar afektif siswa diambil dari kegiatan siswa selama proses pembelajaran berlangsung. Hasil belajar afektif siswa dinilai dan diamati oleh para observer selama proses pembelajaran berlangsung.

Berdasarkan analisis data hasil belajar siswa ranah afektif mengalami peningkatan dari siklus I ke siklus II. Pada siklus I secara klasikal sebesar 70\% meningkat pada siklus II menjadi $80 \%$ menunjukkan peningkatan sebesar $10 \%$. Peningkatan pada siklus II banyak siswa yang aktif mengikuti kegiatan pembelajaran yang aktif baik aspek spirirual maupun sosialnya. Domain afektif adalah reciving (sikap menerima), responding (memberikan respons), valuing (nilai), organization (organisasi), characterization (karakterisasi) (Suprijono, 2011).

\subsection{Hasil Belajar Psikomotor}

Hasil belajar siswa psikomotor yaitu aktivitas siswa yang dinilai meliputi cara siswa menjelaskan, cara siswa praktikum, keaktifan bertanya, cara bekerjasama dengan anggota kelompok. Hasil belajar siswa psikomotor meningkat dari siklus I ke siklus II. Pada siklus I hasil belajar psikomotor siswa secara klasikal sebesar 70\% dan meningkat menjadi $80 \%$ pada siklus II. Hal ini menunjukkan bahwa terjadi peningkatan sebesar $10 \%$. Pada siklus I hasil belajar siswa secara klasikal dapat dikatakan dalam kategori cukup. Persentase ketuntasan yang telah ditetapkan oleh SMP Negeri 22 Malang adalah $\geq 75 \%$ dari jumlah siswa. Hal ini karena aktivitas siswa yang saat menjelaskan masih belum tepat, saat praktikum siswa masih tidak mengetahui prosedur praktikum, siswa tidak banyak bertanya dan kurangnya kerjasama saat diskusi berlangsung.

Pada siklus II secara klasikal hasil belajar psikomotor siswa dikatakan tuntas mencapai persentase klasikal. Hal ini ditunjukkan banyak siswa dapat menjelaskan pertanyaan guru, prosedur praktikum dijelaskan guru sehingga siswa dapat terampil mengerjakan, ada yang mengajukan pertanyaan tentang materi serta terjadi kerjasama yang baik dalam diskusi. Keterampilan motorik yaitu kemampuan melakukan serangkaian gerak jasmani dalam urusan dan koordinasi, sehingga terwujud otomatisme gerak jasmani (Suprijono,2011). 


\subsection{Hasil Belajar Siswa Secara Keseluruhan}

Berdasarkan hasil analisis data hasil belajar siswa dari tiga ranah, yakni ranah kognitif, ranah afektif, dan ranah psikomotor diketahui ketuntasan hasil secara klasikal. Secara klasikal ketuntasan hasil belajar siswa mengalami peningkatan dari siklus I ke siklus II. Hasil belajar klasikal pada siklus I sebesar 67,6 \% sedangkan pada siklus II sebesar $80 \%$. Hal ini menunjukkan terjadi peningkatan pada siklus I dan II sebesar 30,3\%. Ketuntasan belajar secara klasikal dapat dilihat dari banyaknya siswa yang tuntas mencapai KKM yang telah ditetapkan yakni 75. Dari siswa yang tuntas tersebut dapat diketahui ketuntasan belajar secara klasikal dengan ketetapan persentase sebesar $\geq 75 \%$.

Kurang terbiasanya siswa meggunakan model pembelajaran berpengaruh pada hasil belajar kognitif siswa, hasil belajar afektif siswa dan hasil belajar psikomotor siswa. Hal ini dibuktikan dengan siswa belum terbiasa menghadapi permasalahan yang diberikan sehingga kebingungan dalam mengerjakan. Siswa yang aktif 1-3 sehingga diskusi tidak tejadi kerja sama. Penjelasan belum tepat, praktikum siswa tidak mengetahui prosedur praktikum. Siswa yang tidak terlatih keterampilan berpikir, tidak terbiasa aktif di kelas maka berdampak pula terhadap hasil belajar baik kognitif, afektif dan psikomotor. Menurut Ibrahim dan Nur (dalam Rusman, 2010) model PBL dapat membantu siswa mengembangkan keterampilan berpikir dan memecahkan masalah, belajar berbagai peran orang dewasa melalui keterlibatan mereka dalam pengalaman nyata dan menjadi para siswa yang mandiri.

Pada pelaksanaan tindakan siklus II menunjukkan hasil belajar yang baik yang ditunjukkan dengan nilai yang mencapai KKM. Pada siklus II ketuntasan belajar klasikal menjadi $80 \%$ dari siklus I. Peningkatan siswa banyak mengetahui materi dan terbiasa menggunakan model pembelajaran $P B L$. Peningkatan hasil belajar keseluruhan secara klasikal menunjukkan persentase sebesar 30,3\%. Hal ini dibuktikan ketika guru memberikan pertanyaan yang merupakan orientasi terhadap masalah banyak siswa yang dapat menjawab. Pada kegiatan diskusi semua anggota kelompok mengerjakan lembar kegiatan siswa. Tahapan analisis dan evaluasi proses pembelajaran banyak siswa yang mampu memberikan refleksi hasil pembelajaran dengan baik, berpendapat dengan baik. Hal ini menandakan bahwa siswa sudah dapat memecahkan masalah dalam materi yang dibahas sehingga hasil belajar kognitif pada siklus II meningkat dibandingkan siklus I. Rusman (2010) bahwa model $P B L$ adalah penguasaan isi belajar dari disiplin heuristik dan pengembangan keterampilan pemecahan masalah.

Banyak siswa yang aktif mengikuti kegiatan pembelajaran yang aktif baik aspek spirirual maupun sosialnya. Selain itu banyak siswa yang dapat menjelaskan ketika ditanya oleh guru, prosedur praktikum sudah dijelaskan guru sehingga siswa dapat terampil mengerjakan, sudah ada yang mengajukan pertanyaan tentang materi yang diajarkan serta sudah terjadi kerjasama yang baik dalam diskusi. Hasil belajar adalah perubahan perilaku secara keseluruhan bukan hanya salah satu aspek potensi saja (Suprijono, 2011).

Namun demikian masih ada $10 \%$ dari jumlah 30 siswa yang masih belum tuntas pada hasil belajarnya. Hal ini dimungkinkan siswa belum menguasai materi dan belum terbiasa dengan penerapan model pembelajaran $P B L$. Siswa tersebut belum terlatih keterampilan berpikirnya sehingga tidak mampu memecahkan permasalahan yang diberikan oleh guru. Hal ini dapat dilihat dari cara menjelaskan yang masih terlalu sederhana. Guru dapat melatih siswa agar siswa dapat meningkatkan keterampilan berpikir siswa agar dapat memecahkan 
masalah dan mampu mengorganisasi belajar dengan pengalamanya, menghasilkan karya serta mampu menganalisis dan mengevaluasi prose pemecahan masalah tersebut. Berdasarkan kendala tersebut, guru bisa memberikan remedial bagi siswa yang tidak tuntas agar dapat mencapai KKM yang telah ditetapkan. Secara keseluruhan dapat dinyatakan bahwa penerapan model pembelajaran $P B L$ dapat meningkatkan keterampilan berpikir kritis siswa dan hasil belajar siswa kelas VIII SMP Negeri 22 Malang.

\section{Simpulan}

Keterampilan berpikir kritis siswa pada siklus II mengalami kenaikan dibanding siklus I. Rerata keterampilan berpikir siklus 1 sebesar 1,50 yang tergolong kurang kritis dengan persentase sebesar 23\% sedangkan pada siklus II rerata keterampilan berpikir kritis siswa sebesar 2,36 yang tergolong kritis dengan persentase sebesar 76\%. Dari data tersebut menunjukkan bahwa keterampilan berpikir kritis meningkat sebesar 53\%. Secara klasikal ketuntasan hasil belajar siswa mengalami peningkatan dari siklus I ke siklus II. Hasil belajar klasikal pada siklus I sebesar 67,6 \% sedangkan pada siklus II sebesar $80 \%$. Hal ini menunjukkan terjadi peningkatan pada siklus I dan II sebesar 30,3\%. Secara keseluruhan penerapan model pembelajaran PBL dapat meningkatkan keterampilan berpikir kritis siswa dan hasil belajar siswa kelas VIII SMP Negeri 22 Malang. Berdasarkan hasil pembahasan maka disarankan bagi guru sebaiknya lebih memperhatikan siswa yang masih belum menguasai materi, lebih melatih keterampilan berpikir kritis, mendorong siswa untuk berani berpendapat.

\section{Daftar Rujukan}

Barrows, H. S. (1996). Problem-based learning in medicine and beyond: A brief overview. New directions for teaching and learning, 1996(68), 3-12.

Darmawan. (2010). Penggunaan Pembelajaran Berbasis Masalah dalam Meningkatkan Kemampuan Berpikir Kritis Siswa pada Pembelajaran IPS di MI Darussaadah Pandeglang. Jurnal Penelitian Pendidikan, Volume 11, Nomor 2, Oktober 2010, (Online) (http;//jurnal.upi.edu/file/3_darmawan.pdf)

Ennis, R. (1996). Critical Thinking. New Jersey: Simon and Schuster aviacom company.

Ibrahim, Muslimin dan Nur. (2000). Pembelajaran Berdasarkan Masalah. Surabaya: UNESA.

Rusman. (2010). Model-Model Pembelajaran. Bandung: Rajawali Pers.

Slavin, E Roberts. (2010). Cooperative Learning Theory, Riset dan Praktik cetakan VIII. Bandung: Nusa Media.

Sudjana, Nana. (2009). Dasar-Dasar Proses Belajar Mengajar. Bandung: Sinar Baru Algesindo

Suprijono. (2011). Cooperative Learning. Jakarta: Bumi Aksara. 